\title{
IMPLEMENTASI METODE STRING MATCHING UNTUK PENCARIAN BERITA UTAMA PADA PORTAL BERITA BERBASIS ANDROID (STUDI KASUS: HARIAN RAKYAT BENGKULU)
}

\author{
Ernawati $^{1}$, Asahar Johar ${ }^{2}$, Sandi Setiawan ${ }^{3}$ \\ ${ }^{1,2,3}$ Program Studi Informatika, Fakultas Teknik, Universitas Bengkulu \\ J1. W.R. Supratman Kandang Limun Bengkulu 38371A Indonesia \\ (telp: 0736-341022; fax: 0736-341022) \\ lernawatieunib.ac.id \\ 2asahar.johareunib.ac.id \\ ${ }^{3}$ sandigla010@gmail.com
}

Abstrak: Pencocokan string merupakan bagian penting dari sebuah proses pencarian string (string searching) dalam sebuah dokumen. Hasil dari pencarian sebuah string dalam dokumen tergantung dari teknik atau cara pencocokan string yang digunakan. portal berita memiliki satu server dan 10 administrator berdasarkan 10 Kabupaten/Kota, dimana aplikasi server memiliki klasifikasi berdasarkan hot news, kategori berita, dan pencarian berita. Sedangkan pada client akan menampilkan informasi secara online klasifikasi berdasarkan hot news, kategori berita, dan pencarian berita. Hal ini didukung dengan perkembangan akses internet yang semakin pesat, sehingga setiap orang di dunia dapat mengakses atau memberikan informasi secara real time (tanpa adanya jeda waktu). hasil dari implementasi dapat menerapkan metode string matching pada berita utama, sehingga dapat menarik minat pembaca bukan hanya dari tulisan yang baik dan mudah dipahami melainkan melalui gambar berdasarkan kategori berita, Kabupaten, serta pewarta berita. Diharapkan untuk kedepannya aplikasi ini diharapkan dapat dikembangkan dengan algoritme ataupun metode yang lain, sehingga dapat mengetahui secara pasti algoritme ataupun metode apa yang sesuai dalam aplikasi portal berita.

Kata Kunci: String, Pencarian, Android, Berita, Website.

\begin{abstract}
String matching is an important part of a string searching process in a document. The result of searching a string in a document depends on the technique or method of matching the string used. News portals have one server and 10 administrators based on 10 districts / cities, where application servers have classifications based on hot news, news categories, and news searches. While the client will display online classification information based on hot news, news categories, and news searches. This is supported by the development of increasingly rapid internet access, so that everyone in the world can access or provide information in real time (without any lag). the results of the implementation can apply the string matching method to the headlines, so that it can attract readers' interest not only from good and easy to understand writing but through images based on news categories, regencies, and news reporters. It is expected that in the future this application is
\end{abstract}

expected to be developed with algorithms or other methods, so that it can know exactly what algorithms or methods are appropriate in the news portal application.

Keywords: String, Search, Android, News, Website.

\section{Pendahuluan}

Di era global seperti saat ini, internet sudah merambah berbagai bidang misalnya sosial, periklanan, dan bisnis. Sejalan dengan kemajuan internet tersebut, banyak berita yang disajikan melalui internet. Beberapa website penyedia berita menambahkan fasilitas RSS (really simple syndication). RSS digunakan untuk menyebarkan ringkasan tulisan terbaru. Untuk menampilkan 
Jurnal Pseudocode, Volume VI Nomor 1, Februari 2019, ISSN 2355-5920, e-ISSN 2655-1845 www.ejournal.unib.ac.id/index.php/pseudocode

berita dari website yang mempunyai fasilitas RSS dibutuhkan sebuah aplikasi yang disebut news reader. News reader adalah sebuah perangkat lunak atau layanan website yang berfungsi untuk menampilkan ringkasan tulisan terbaru seperti tajuk berita, blog, podcast, dan video blog pada suatu lokasi agar mudah dibaca

Untuk mempermudah dalam pengaksesannya, portal berita tersebut dibuat dalam bentuk aplikasi perangkat bergerak. Adapun beberapa kemudahan mengakses berita melalui perangkat bergerak ialah dapat diakses dimana saja dan kapan saja. Selain itu konten pada aplikasi tidak terbatas hanya pada teks maupun gambar melainkan juga berupa video. Dalam pembuatan portal berita berbasis aplikasi perangkat bergerak, terdapat beberapa library yang dapat digunakan. Tujuan penggunaan library ialah untuk mempermudah proses pembuatan aplikasi

Dalam penelitian ini, portal berita memiliki satu server dan 10 administrator berdasarkan 10 Kabupaten/Kota, dimana aplikasi server memiliki klasifikasi berdasarkan hot news, kategori berita, dan pencarian berita. Sedangkan pada client akan menampilkan informasi secara online klasifikasi berdasarkan hot news, kategori berita, dan pencarian berita. Dalam pencarian berita, aplikasi ini menggunakan metode string matching. String matching merupakan sebuah algoritme yang digunakan dalam pencocokkan suatu pola kata tertentu terhadap suatu kalimat atau teks panjang. Algoritme string matching sendiri dapat dilakukan dengan beberapa cara tertentu.

Dalam dunia jurnalistik, perkembangan teknologi dapat menjadi hal yang positif. Proses penyampaian berita atau informasi kepada masyarakat menjadi lebih mudah dan cepat tanpa adanya batasan jarak dalam mengakses berita tersebut. Hal ini didukung dengan perkembangan akses internet yang semakin pesat, sehingga setiap orang di dunia dapat mengakses atau memberikan informasi secara real time (tanpa adanya jeda waktu). Menanggapi perkembangan informasi tersebut, penulis berniat untuk membuat sebuah aplikasi Portal Berita Harian Rakyat Bengkulu Berbasis Android.

Dengan menggunakan algoritme string matching sendiri dapat dilakukan dengan beberapa cara tertentu, sehingga untuk mencari sebuah berita lebih cepat dan mudah. Dengan adanya portal berita ini, Harian Rakyat Bengkulu dapat memberikan berbagai informasi atau berita secara cepat kepada masyarakat tanpa adanya batasan jarak dan waktu. Cukup dengan menggunakan sebuah smartphone dan akses internet, pembaca dapat menikmati berbagai berita di Harian Rakyat Bengkulu.

Dari uraian di atas, tertarik untuk melakukan penelitian dengan judul Implementasi Metode String Matching Untuk Pencarian Berita Utama Pada Portal Berita Berbasis Android (Studi Kasus: Harian Rakyat Bengkulu).

\section{LANDASAN TEORI}

\section{A. Pengertian Sistem Informasi}

Sistem dapat didefinisikan sebagai sekumpulan objek, ide, saling keterhubungannya (inter-relasi) dalam mencapai tujuan atau sasaran bersama [1].

\section{B. Metode String Matching}

Menurut Rosaria (2015:1) algoritme string matching adalah sebuah algoritme yang digunakan dalam pencocokkan suatu pola kata tertentu terhadap suatu kalimat atau teks panjang. Algoritme string matching sendiri dapat dilakukan dengan beberapa cara tertentu, antara lain cara Brute Force dan cara Knuth-Morris-Pratt (KMP) [2]. 
Jurnal Pseudocode, Volume V Nomor 2, September 2018, ISSN 2355-5920, e-ISSN 2655-1845 www.ejournal.unib.ac.id/index.php/pseudocode

Menurut Syaroni (2012:1) Pengertian string menurut Dictionary of Algorithms and Data Structures, National Institute of Standards and Technology (NIST) adalah susunan dari karakterkarakter (angka, alfabet atau karakter yang lain) dan biasanya direpresentasikan sebagai struktur data array. String dapat berupa kata, frase, atau kalimat.

Pencocokan string merupakan bagian penting dari sebuah proses pencarian string (string searching) dalam sebuah dokumen. Hasil dari pencarian sebuah string dalam dokumen tergantung dari teknik atau cara pencocokan string yang digunakan. Pencocokan string (string matching) menurut Dictionary of Algorithms and Data Structures, National Institute of Standards and Technology (NIST), diartikan sebagai sebuah permasalahan untuk menemukan pola susunan karakter string di dalam string lain atau bagian dari isi teks.

\section{Aplikasi}

Aplikasi berasal dari kata aplication yang artinya penerapan, lamaran, penggunaan. Secara istilah aplikasi adalah program siap pakai yang direka untuk melaksanakan suatu fungsi bagi pengguna atau aplikasi yang lain digunakan untuk satu tujuan [3].

\section{D. $P H P$}

PHP Hypertext Preprocessor

(PHP) merupakan sebuah script open source multifungsi yang sangat sesuai untuk pengembangan sebuah website dan bisa digabungkan ke dalam Hypertext Markup Language (HTML). Hal yang membedakan antara PHP dengan produk lain yang sejenisnya adalah bahwa eksekusi dari kode-nya dilakukan pada sisi server. Ini berarti client tidak akan bisa mengetahui pemrograman seperti apa yang akan dibuat.
Menurut Nugroho (2012), pengertian PHP merupakan standar yang digunakan dalam dunia website, PHP adalah bahasa program yang berbentuk skrip yang diletakan di dalam server $w e b$. Adapun pengertian PHP dalam penelitian ini adalah sebagai program dalam pembuatan aplikasi pembelajaran bahasa inggris

E. SQL

MySQL adalah sebuah database relasional gratis dan open source yang mula-mula tersedia di Unix/Linux namun kini tersedia juga di sistem operasi Windows. MySQL mulai populer sejak pertengahan 1990-an saat Web dan aplikasi web mulai popular. Saat itu, selain MySQL, tidak ada alternatif database lain yang cepat, stabil, dan memiliki fitur-fitur yang cukup untuk bisa dijadikan database pendukung aplikasi. Hingga kini MySQL terus bertahan sebagai database open source yang paling populer mengalahkan PostgreSQL, interbase/firebird, dan lain sebagainya. MySQL mudah diinstal, mudah dipakai dan dapat dikoneksikan dari berbagai bahasa pemrograman (Sidik, 2006)

\section{F. Unified Modelling Language}

Unified Modeling Language (UML) merupakan bahasa pemodelan visual yang bersifat general purpose yang digunakan untuk spesifikasi, visualisasi, membangun, dan dokumentasi artifak dari sebuah system perangkat lunak. UML menangkap keputusan serta pemahaman mengenai sistem yang akan dibangun. UML ditujukan untuk penggunaan pada semua metode pengembangan, tahapan daur hidup, domain aplikasi, dan media [4]. 
Jurnal Pseudocode, Volume VI Nomor 1, Februari 2019, ISSN 2355-5920, e-ISSN 2655-1845 www.ejournal.unib.ac.id/index.php/pseudocode

\section{MetodologI}

Langkah-langkah yang dilakukan dalam penelitian ini adalah:

1. Observasi

Penulis melakukan pengamatan secara langsung untuk mengetahui informasi berita pada Harian Rakyat Bengkulu, meliputi berita utama, berita berdasarkan Kabupaten/ Kota.

2. Studi Pustaka

Studi pustaka adalah suatu metode pengumpulan data yang diambil dari perpustakaan atau instansi yang berupa karya ilmiah, jurnal, buku-buku serta dari internet yang berhubungan dengan penulisan ini. Tujuan dari studi pustaka ini adalah untuk mendalami dan memperoleh keterangan yang lengkap terhadap obyek yang diteliti.

\section{ANALISIS DATA DAN PERANCANGAN}

\section{A. Identifikasi Masalah}

Menanggapi perkembangan informasi Portal

Berita Harian Rakyat Bengkulu, proses penyampaian berita atau informasi kepada masyarakat menjadi lebih mudah dan cepat tanpa adanya batasan jarak dalam mengakses berita tersebut. dapat memberikan berbagai informasi atau berita secara cepat kepada masyarakat tanpa adanya batasan jarak dan waktu.

Pencarian sebuah string dalam dokumen tergantung dari teknik atau cara pencocokan string yang digunakan. Pencocokan string (string matching) menurut Dictionary of Algorithms and Data Structures, National Institute of Standards and Technology (NIST), diartikan sebagai sebuah permasalahan untuk menemukan pola susunan karakter string di dalam string lain atau bagian dari isi teks. Dimana pencocokan string dimana string yang dicocokkan memiliki kemiripan dimana keduanya memiliki susunan karakter yang berbeda (mungkin jumlah atau urutannya) tetapi stringstring tersebut memiliki kemiripan baik kemiripan tekstual/penulisan (approximate string matching).

B. Analisis Alir Kerja Sistem

Alur sistem akan memudahkan dalam mengimplementasikan rancangan kedalam sistem yang akan dibangun dapat dilihat pada Gambar 1.

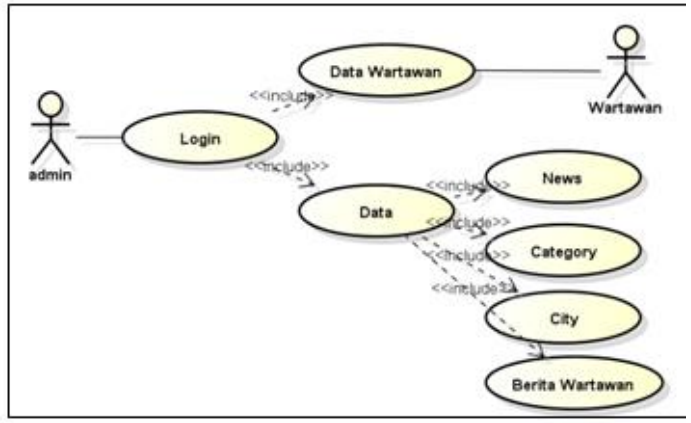

Gambar 1. Diagram Usecase Admin

C. Perancangan Sistem

Dibawah ini merupakan perancangan sistem menggunakan Unified Modeling Language (UML).

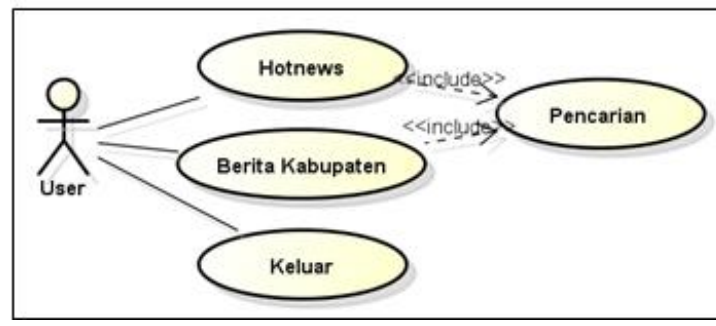

Gambar 2. Usecase Diagram user

\section{PEMBAhasan}

\section{A. Implementasi Sistem}

Setelah melakukan perancangan, maka selanjutnya adalah implementasi sistem.

a. Halaman Login

Pada Gambar 3 merupakan sistem keamanan standar dari aplikasi, dimana untuk dapat masuk pada halaman utama harus melakukan input username dan password. 
Jurnal Pseudocode, Volume V Nomor 2, September 2018, ISSN 2355-5920, e-ISSN 2655-1845 www.ejournal.unib.ac.id/index.php/pseudocode

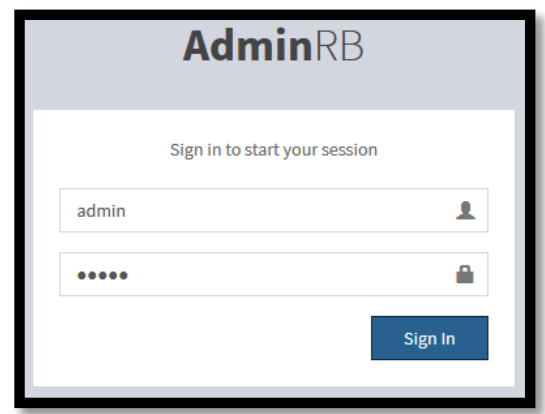

Gambar 3. Halaman Login

b. Halaman Beranda

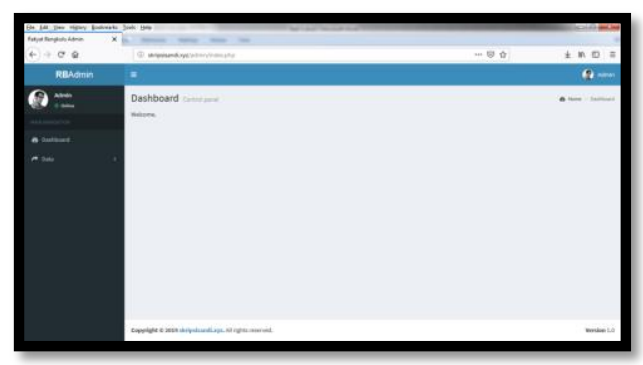

Gambar 4. Halaman Beranda

Pada Gambar 4 merupakan halaman server dimana terdapat 4 menu, yaitu news, berita kabupaten, login wartawan dan pengelola.

c. Halaman News

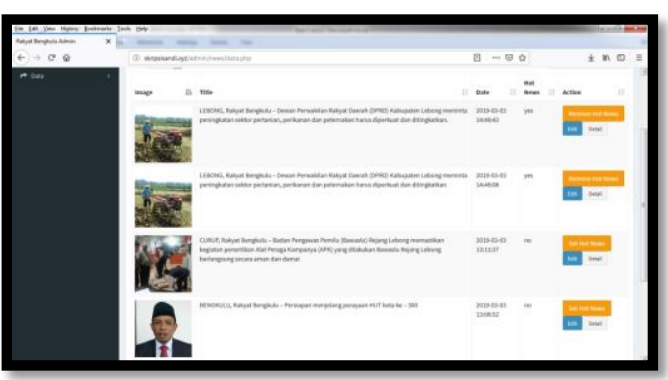

Gambar 5. Halaman News

Merupakan input data news berdasarkan data Kabupaten dan hotnews.

d. Halaman Splash Screen

Tampilan splash screen merupakan tampilan selamat datang dalam aplikasi ini, berisikan informasi gambar kantor Harian Rakyat Bengkulu selama 5 detik.

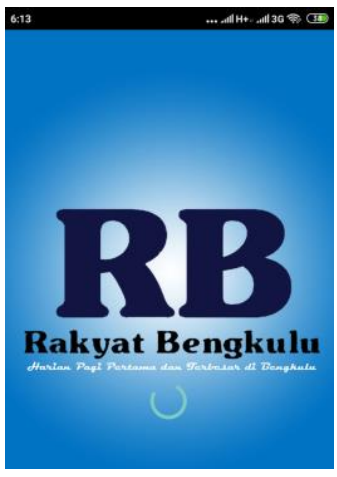

Gambar 6. Halaman Splash screen

e. Halaman Menu Utama

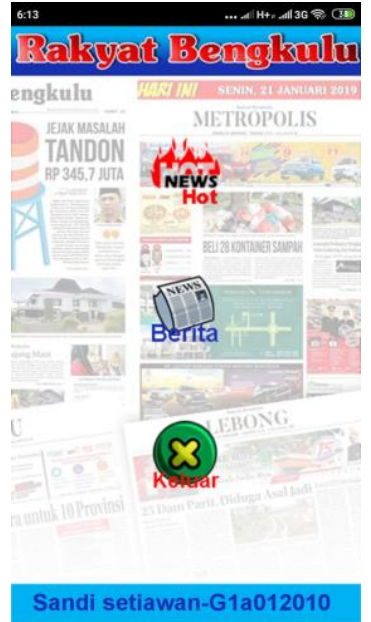

Gambar 7. Halaman Menu Utama

Pada halaman utam terdapat 3 menu yaitu newspaper, berita, dan pencarian berita.

f. Halaman Newspaper
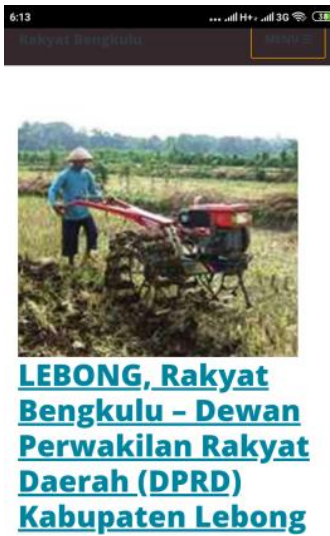

Gambar 8. Halaman Newspaper

Pada halaman newspaper merupakan tampilan awal berita yang penting. 
Jurnal Pseudocode, Volume VI Nomor 1, Februari 2019, ISSN 2355-5920, e-ISSN 2655-1845 www.ejournal.unib.ac.id/index.php/pseudocode

g. Halaman Berita

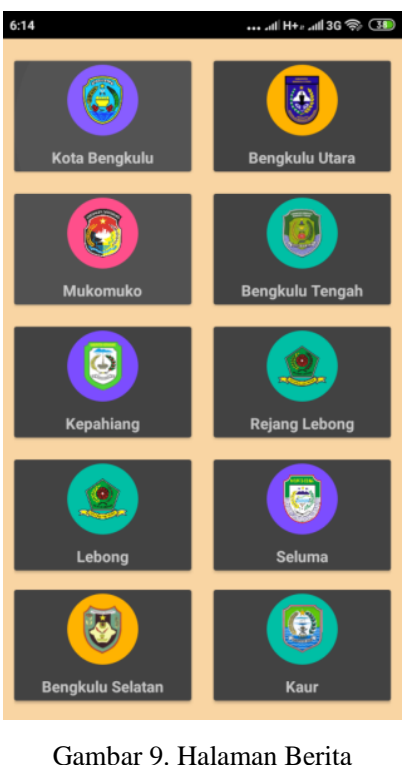

Pada halaman berita merupakan tampilan berita berdasarkan Kabupaten.

\section{KESIMPULAN}

\section{A. Kesimpulan}

Setelah melakukan evaluasi terhadap pengerjaan penelitian aplikasi metode string matching untuk pencarian berita utama pada portal berita berbasis android (Studi Kasus: Harian Rakyat Bengkulu), ada beberapa kesimpulan yang didapatkan yaitu :

1. Telah berhasil membangun sistem aplikasi metode string matching untuk pencarian berita utama pada portal berita berbasis android (Studi Kasus : Harian Rakyat Bengkulu) dengan menggunakan 2 aplikasi yaitu PHP dan android studio dengan 1 database yaitu SQL.

2. Dapat menerapkan metode string matching pada berita hotnews, sehingga dapat menarik minat pembaca bukan hanya dari tulisan yang baik dan mudah.

B. Saran

Adapun beberapa saran yang perlu dikembangkan dalam aplikasi metode string matching untuk pencarian berita utama pada portal berita berbasis android (Studi Kasus: Harian Rakyat Bengkulu) yaitu:

1. Untuk kedepannya aplikasi ini diharapkan dapat dikembangkan dengan video sehingga dapat menghasilkan portal berita yang digital.

2. Untuk kedepannya aplikasi ini diharapkan dapat dikembangkan dengan algoritma ataupun metode yang lain, sehingga dapat mengetahui secara pasti algoritma ataupun metode apa yang sesuai dalam aplikasi portal berita.

3. Untuk kedepannya aplikasi ini diharapkan dapat dikembangkan dalam penambahan animasi sehingga aplikasi ini lebih dinamis.

\section{REFERENSI}

[1] Prahasta, E. (2007). In Konsep Perancangan Sistem Informasi Geografis (p. 83). Bandung: Informatika.

[2] Rosaria, Maya. 2015. Implementasi Algoritma Pencocokan String Knuth morris-Pratt Dalam Aplikasi Pencarian Dokumen Digital Berbasis Android. Jurnal Rekursif, Vol. 3 No. 2 November 2015, ISSN 2303-0755

[3] Tirtobisono, R. (2009). In Pengenalan Dasar Visual Basic 6.0 (p. 68). Yogyakarta: Andi Offset.

[4] Robert Theophani Singkoh, A. S. (2016). Perancangan Game FPS (First Person Shooter) Police Personal Training. E-Journal Teknik Elektro dan Komputer Vol.5 No.1 Januari-Maret 2016, ISSN : 23018402, 7. 